\title{
Donkey's Milk in the Management of Children with Cow's Milk protein allergy: nutritional and hygienic aspects
}

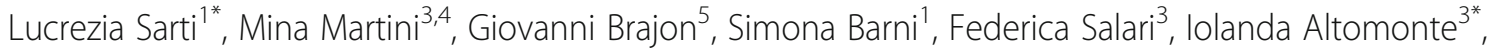 \\ Giuseppe Ragona ${ }^{5}$, Francesca Mori ${ }^{1}$, Neri Pucci ${ }^{1}$, Giada Muscas ${ }^{2}$, Fina Belli ${ }^{2}$, Franco Corrias ${ }^{5}$ and Elio Novembre ${ }^{1}$
}

\begin{abstract}
Background: The therapeutic strategy for children with cow's milk allergy (CMA) consists in the elimination of cow's milk (CM) from their diet. Donkey's milk (DM) has been reported to be an adequate alternative, mainly to his nutritional similarities with human milk (HM) and excellent palatability. The aim of present prospective study was to evaluate the nutritional impact of DM on the diet of children with CMA in term of children growth.

Methods: Before the nutritional trial on children and during the study the health and hygiene risks and nutritional and nutraceuticals parameters of DM were monitored. Children with CMA were identified by the execution of in vivo and in vitro tests for CM and subsequent assessment of tolerability of DM with oral food challenge (OFC). Finally, we prescribed DM to a selected group of patients for a period of 6 months during which we monitored the growth of children. A total of 81 children, 70 with IgE mediated cow's milk protein allergy (IgE-CMPA) and 11 with Food Protein Induced Enterocolitis Syndrome to CM (CM-FPIES), were enrolled.

Results: Seventy-eight out of 81 patients underwent the OFC with DM and only one patient with IgE-CMPA (1.5\%) reacted. Twenty-two out of 81 patients took part of the nutritional trial. All the 22 patients took and tolerated the DM, moreover DM did not change the normal growth rate of infants.

Conclusions: In conclusion, DM resulted safe in term of health and hygiene risks and nutritionally adequate: no negative impact on the normal growth rate of children was assessed. Therefore, it may be a suitable alternative for the management of IgE mediated CMA and FPIES, also in the first 6 months of life, if adequately supplemented.
\end{abstract}

Keywords: Children, cow's milk allergy, donkey milk, Hygienic risk, Nutritional, Nutraceutical

\section{Background}

Human milk (HM) is the exclusive or primary supply in the first months of a new-born's life [1], but in cases where it is not available it becomes essential to provide a suitable alternative. Cow's milk (CM) based formulas are widely used as a substitute for HM, however $2-3 \%$ of children present an IgE-mediated cow's milk protein allergy (IgE- CMPA) [2,3] and it is also known that in the $0.34 \%$ of children, CM can cause the Food Protein Induced Enterocolitis Syndrome (CM-FPIES) [4].

\footnotetext{
* Correspondence: lucrezia.sarti@gmail.com; altomonte@vet.unipi.it

${ }^{1}$ Allergy Unit, department of Paediatrics, Anna Meyer Children's University Hospital, Florence, Italy

${ }^{3}$ Department of Veterinary Science, University of Pisa, Pisa, Italy

Full list of author information is available at the end of the article
}

The therapeutic strategy for children with IgE-CMPA or CM-FPIES consists of the total elimination of cow's milk protein (CMP) from their diet $[4,5,7]$. During the first years of life, milk represents an important source of nutrients, so it's difficult to eliminate from the everyday diet. Therefore, one of the major objectives of paediatric allergists is to find an appropriate alternative with a pleasant taste, good nutritional values, and hypoallergenic properties that will not induce cross-reactivity with CM [6]. The current guidelines [2, 8-13] recommend extensively hydrolyzed formulas (eHFs) as the first choice with IgE-CMPA treatment except for the more severe reactions where free amino acid formulas (FAAFs) are preferable. Unfortunately, eHFs and FAAFs are hampered by their unpleasant taste not only related

(C) The Author(s). 2019 Open Access This article is distributed under the terms of the Creative Commons Attribution 4.0 International License (http://creativecommons.org/licenses/by/4.0/), which permits unrestricted use, distribution, and 
to the hydrolysis itself but also to their particular composition (eg fatty acid profile) and by the possibility of residual allergenicity [14-17]. While soy infant formula can be considered a good additional alternative choice because it is readily available, has an acceptable taste, and ensures proper growth in children, it is not recommended as a first choice either for IgE-CMPA treatment, especially in infants younger than 6 months, because of the major risk of developing allergy to soy $[18,19]$, or for CM-FPIES treatment because a large percentage of these infants can also react to soy [20-22].

Donkey's milk (DM) has recently received growing interest as has been reported to be an adequate alternative for children with CMPA and CM-FPIES, mainly due to its nutritional similarities with human milk [23] and excellent palatability and tolerability [24-29], unlike the milk of other species, such as goat's and sheep's milk, which can lead to cross-reactivity between their proteins and CM proteins [17, $30,31]$. In fact, DM shows a protein fraction more similar to HM than CM, in addition to which, the primary structure of DM's caseins presents significant differences compared to other species, and it is always more closely related with HM counterparts [18, 32-34]. This may contribute towards explaining the less allergenic properties of DM and its greater digestibility [35]. Furthermore, the high lactose content of DM confers good palatability.

The stimulatory effect of lactose on intestinal calcium absorption - known for its important role in bone mineralization - has been observed in animal models [36], while there are contradictory reports in humans [37].

Among other positive properties, DM also has a high content of lysozyme which, together with immunoglobulins, lactoferrin, and lactoperoxidase, exerts both an immunoregulatory and an anti-tumour activity, and it may also act on the digestive tract by reducing the incidence of gastro-intestinal infections [18, 25, 31, 32, 38].

However, DM has a low-fat content, which corresponds to a low energetic value [25]. While the low lipid content of DM can be considered an advantage in low calorie diets or when a low intake of animal fat is recommended, it may represent a limit in children who require an adequate intake of lipids. In fact, lipids represent 50\% up to 12 months and about $40 \%$ between 12 months and 24 months of age of daily caloric needs; therefore, if donkey milk is administered as the sole source of nutrition, it must be adequately supplemented with lipids.

The number of studies that focus on the hygiene and health characteristics of DM is increasing [39]. There are reports that show the interactivity of lysozyme and lactoferrin may affect the antimicrobial properties of DM [40] and that the consumption hazards of DM are lower than for CM, especially for microorganisms like enterotoxigenic E. coli and thermotolerant Campylobacter [41]. Moreover, the low prevalence of mastitis agents in DM has been demonstrated [39, 42]. As pathogenic bacteria and DNA from protozoa have been found in DM [42, 43], due to its use in sensitive consumers, heat treatment of raw milk is recommended to avoid the risk of food-borne diseases. Pasteurisation guarantees both the preservation of the milk's nutritional properties and the elimination of any pathogenic microorganisms that could be present in raw milk.

The main purpose of this study is to evaluate the nutritional impact of DM, appropriately integrated, on the diet of patients with IgE-CMPA and CM-FPIES in terms of children's growth. For this purpose a multidisciplinary and prospective study tested the nutritional and nutraceutical characteristics and sanitation of DM, as well as its palatability and tolerability.

\section{Methods}

DM was supplied from a farm located in central Italy, where about 160 Amiata donkeys are reared outdoors, in a semi-intensive system and routinely machine milked twice a day. The farm has been recognised according to European Union (EU) regulation 853/2004.

Before the nutritional trial on children and during the study, the health and hygiene risks and nutritional and nutraceuticals parameters were monitored by the Istituto Zooprofilattico Sperimentale del Lazio e della Toscana (Florence section-Florence, Italy) and the Department of Veterinary Sciences of the University of Pisa (Italy) respectively. The palatability and tolerability of the milk were assessed by the Department of Allergy of the Anna Meyer Children's Hospital (Florence, Italy): a specific allergological work-up that included skin tests, in vitro tests and oral provocation tests with DM was performed in a day-hospital setting in children with IgE-CMPA or CMFPIES. The Department of Allergy and Professional dietetic Unit also drew up nutritional plans that included DM, adapted to the needs of patients with IgE-CMPA and CM-FPIES in relation to their age, sex and disease. The same departments monitored the palatability of DM and the growth and the quality of life of the children enrolled in the study for a period of 6 months.

\section{Evaluation of the health hazards of DM consumption and nutritional and nutraceutical analyses}

The health and hygiene risk analyses were carried out on 36 bulk milk samples (18 of raw milk and 18 of the corresponding milk pasteurised at $65^{\circ} \mathrm{C}$ for $30 \mathrm{~min}$ ) taken monthly, while the nutritional analysis regarded the pasteurised samples. All the samples were taken to the laboratories in tanks at $4{ }^{\circ} \mathrm{C}$; no preservatives were added. Microbiological analyses required by European (EC Regulation 853/2004) and Italian national legislation (Intesa Stato-Regioni 25 January 2007) were conducted on the raw milk samples. In particular, the hygienic quality of the milk was studied by determining the Total Viable Count (TVC) at $30^{\circ} \mathrm{C}$ [UNI EN ISO (Italian National Unification Body), 4833-1: 2013], and the 
food safety via the occurrence of the main pathogenic bacteria responsible for food-borne infections: Salmonella spp. (ISO 6579:2002/Cor 1: 2004), Listeria monocytogenes (UNI EN ISO 11290-1: 2005), Campylobacter spp. (UNI EN ISO 11290-1: 2005) and coagulase-positive Staphylococci (ISO 6888-2: 1999/Amd 1:2003). Furthermore, TVC and Enterobacteria (ISO 21528-2: 2004a) (process hygiene criterion provided for by EC Regulation 2073/2005), and coagulasepositive Staphylococci were performed on the pasteurised milk samples. The occurrence of $L$. monocytogenes was also determined in the pasteurised milk samples, as required by the HACCP manual of the farm.

All the samples were analysed for dry matter and lactose content via infrared analysis (Milkoscan, Italian Foss Electric, Padova, Italy); proteins, caseins and ashes [44]. Fat was gravimetrically determined after extraction as per the Rose-Gottlieb method [45]. The individual mineral content $(\mathrm{Ca}, \mathrm{P}$, $\mathrm{Mg}, \mathrm{K}, \mathrm{Na}, \mathrm{Zn})(\mathrm{mg} / \mathrm{L})$ was determined by atomic absorption spectroscopy and ultraviolet-visible spectroscopy according to the AOAC (2000) [46], and Murthy and Rhea (1967) [47]. Methyl esters of fatty acids for gas chromatographic analysis were prepared using methanolic sodium methoxide according to Christie (1982) [48]. The gas chromatographic analysis of the milk was conducted as described in the paper by Ragona et al., 2016 [39].

For the Vitamin D quantification, lipids from $75 \mathrm{ml}$ of DM were saponified by adding $\mathrm{KOH}$ pellets directly to the milk according to Perales et al. (2005) [49] at $40{ }^{\circ} \mathrm{C}$ for $32 \mathrm{~min}$. Ethanol and double distilled water were then added to the sample in order to remove the polar compounds and prevent foaming. Afterwards the solution was transferred into a 500-mL separatory funnel, and an initial extraction of the unsaponifiable fraction was performed using $75 \mathrm{ml}$ hexane. The aqueous phase was thus drained and collected in order to repeat two extractions by adding $75 \mathrm{ml}$ of hexane each time and the organic phase from both was collected in a rotavapor flask. Finally, the organic phase was evaporated to dryness on a rotary evaporator and the extract re-suspended in $500 \mu \mathrm{l}$ of acetonitrile and filtered through a $0.45-\mu \mathrm{m}$ diameter syringe filter. $100 \mu \mathrm{l}$ of the extract were injected into an HPLC and isocratically eluted using acetonitrile-methanol 97: 3 as a mobile phase at a flow of $1 \mathrm{ml} / \mathrm{min}$, as described by Hagar et al. (1994) [50]. A Kinetex core-shell column (Phenomenex, Inc. A) was used as the stationary phase and the UV detector was set at 254 $\mathrm{nm}$. Cholecalciferol and ergocalciferol in the milk samples were quantified by comparison with a calibration curve obtained via the injection of the pure standards (Sigma Chemical Co., St. Louis).

The activity of the lysozyme was assessed by the Fluorimetric method on a microplate (EnzChek Lysozyme Kit, Invitrogen, Carlsbad CA, USA), measured by means of a Spectrofluori Meter (Ascent, Thermo Labsystem FL, USA) and expressed in units $/ \mathrm{ml}$.

\section{Allergological work-up and palatability assessment}

This was a prospective study that recruited 81 children referred to the Allergy Unit of the Anna Meyer Children's Hospital: 70 children ( 45 males, 25 females; age-range 6 months 18 years, mean $5.2 \pm 5.3$ years) with proven IgE-CMPA and 11 patients with proven IgE-FPIES ( 4 males, 7 females; age-range 3 months -8 months, mean $4.73 \pm 1.68$ months).

The allergological work-up included: skin prick test (SPT), specific serum IgE (s-IgE) and oral food challenge (OFC) with DM. The OFC was performed in patients with IgE CMPA according to the DRACMA guidelines and to the protocol of Leonard et al. in patients with IgE-FPIES [29, 51-53].

While performing the OFC we also evaluated the palatability of the DM: in children $\geq 3$ years of age, DM palatability was assessed with a specific Wong-Baker modified pain scale while in children $<3$ years of age it was assessed through the physician's judgment [53]. Before beginning the study informed parental consent was given.

\section{Development of nutritional plans and monitoring growth}

The Department of Allergy and the Professional dietetic Unit of the Anna Meyer Children's Hospital drew up nutritional plans which included DM and were appropriate for the needs of 16 out of the 70 patients with IgECMPA (12 M: 4.F) and 6 out of the 11 patients with CM-FPIES (4 M: 2 F), who referred to the Allergy Unit.

On the basis of the DM nutritional analyses, a number of different nutritional plans were formulated with an appropriate daily calorie intake depending on the age of the patients (Table 1). For children older than 3 years in which milk accounts for less than $10 \%$ of calories, we estimated that its replacement with DM does not give rise to significant variations. The daily-prescribed dose of DM varied depending on age (Table 1). DM was provided free of charge by the Meyer Children Hospital to all children enrolled for the six-month study period. In addition, we prescribed vitamin D (cholecalciferol, Vitamin D3) in specific doses for each age and included a supplement of fat content in the nutritional plans due to the low-fat content in DM (Table 1). Lipid supplementation consisted of $3 \mathrm{~g}$ of lipids for every $100 \mathrm{ml}$ of donkey milk taken, in the form of extra virgin olive oil for children over 6 months of age, to be added either to the milk itself or to savoury meals; in infants younger than 6 months the aforementioned lipid supplementation is half represented by extra virgin olive oil and half by a gluco-lipid supplement to be mixed with donkey's milk. The gluco-lipidic supplement contains $40 \%$ of MCT lipids in its lipid fraction. Also, Vitamin D supplement was provided free of charge during the period of the study.

The patients enrolled in the study met with a dietician three times during the six-month study period: at the beginning (T0) and at the end of the study (T1) in order 
Table 1 The nutritional plans formulated for the 22 patients enrolled in the nutritional trial

\begin{tabular}{lllll}
\hline $\begin{array}{l}\text { Age of } \\
\text { patients }\end{array}$ & $\begin{array}{l}\text { Number of } \\
\text { nutritional } \\
\text { plans }\end{array}$ & $\begin{array}{l}\text { Prescribed daily dose of donkey } \\
\text { milk }\end{array}$ & $\begin{array}{l}\text { Vitamin D } \\
\text { supplement }\end{array}$ & Fat addition to the diet \\
\hline$<6$ & $5^{\text {b }}$ & $\begin{array}{l}500-1000 \mathrm{ml} \text { according to the age } \\
\text { (from } 3 \text { months to one year). }\end{array}$ & $\begin{array}{l}2600 \mathrm{UI} / \\
\text { week }\end{array}$ & $\begin{array}{l}3 \mathrm{~g} \text { of fat in each } 100 \mathrm{ml} \text { of DM [1.5 g of Extra Virgin olive Oil (EVO) and } \\
1.5 \mathrm{~g} \text { of Medium Chain Triglycerides vegetable oil (MCT oil)] }\end{array}$ \\
$\begin{array}{llll}\text { mo } \\
\text { mo } 12\end{array}$ & 1 & & $\begin{array}{l}\text { Addition of fat to the daily meals (for example EVO at lunch and dinner } \\
\text { or a snack in the afternoon to be eaten together with bread). }\end{array}$ \\
$1-3$ y & 1 & $200-250 \mathrm{ml}$ & $\begin{array}{l}4000 \mathrm{UI} / \\
\text { week. }\end{array}$ &
\end{tabular}

DM donkey milk, mo months, $y$ years

${ }^{a}$ un-weaned infants; ${ }^{b}$ one for each month of age

to monitor the nutritional conditions. The patients were also evaluated at 3 months to monitor the compliance of the nutritional plan with its supplements. During the first visit, the dietician explained to parents the nutritional plan specifically designed for their children, the nutritional, nutraceutical and hygienic characteristics of Amiatina $\mathrm{DM}$, the importance of the supplements of fat content and vitamin D, the methods of DM supply and procedures for storing and consuming DM at home. The dietician together with the paediatric allergist also explained the correct reading of the labels to avoid accidentally taking of CM. During the follow-up period the parents kept a food diary, recording daily DM consumption and the related fat and vitamin D supplements, in order to implement changes to the nutritional plan, where necessary.

In addition, the nutritional status of the patients was assessed with blood biochemical parameters and auxological parameters. The biochemical parameters of nutritional interest measured included: blood count (in particular red blood cells and haemoglobin), serum albumin, 25-OH vitamin D level, azotaemia and thyroid function tests (TSH, fT4). Blood was drawn in the Allergy Unit at the beginning of the study (T0) and after 6 months of DM consumption (T1). The nutritional state was also evaluated with auxological parameters which considered weight and body length for children and infants up to 2 years, and stature thereafter. Weight was measured with electronic integrating scales (SECA 757; Hamburg, Germany: precision $\pm 1.0 \mathrm{~g}$ ). Supine length was measured with a Harpenden infant meter and stature was measured with a Harpenden stadiometer. The weight was expressed in kilograms $(\mathrm{kg})$ and the growth curves used were those of the World Health Organisation (WHO) for children and infants up to 2 years of age [54], and the Central Disease Control (CDC) for children over 2 years of age [55]. The length/height was expressed in centimetres $(\mathrm{cm})$ and the growth curves used were those of the $\mathrm{WHO}$ for children up to 2 years of age and those of the CDC for children over 2 years of age. The auxological parameters were collected at $\mathrm{T} 0$ and $\mathrm{T} 1$.

Moreover, weight and length/stature-gain were evaluated in terms of Z-score This method evaluates changes in anthropometric parameters associated with the introduction of DM. Z-score for weight and length/stature-gain were calculated at $\mathrm{T} 0$ and $\mathrm{T} 1$ in the 16 patients with IgE-CMPA and the 6 patients with CM-FPIES. We also focused on the weight and length/stature- gain in terms of Z-score at $\mathrm{T} 0$ and $\mathrm{T} 1$ in the patients younger than 1 year in which milk consumption is relevant.

\section{Statistical analysis}

Health data and chemical composition of DM are reported as mean and standard deviation (SD). Z-scores of weight and length/stature for age were calculated from the formula $\mathrm{Z}=\mathrm{x}-|\mathrm{X}| /|\mathrm{SD}|$, taking the Gardner and Pearson growth curves as reference for children up to 2 years and the Tanner curves after 2 years of age. Z-score values obtained between check-ups were analysed with the paired $\mathrm{t}$-test. Significance was established with the paired $\mathrm{t}$-test, with $p<0.05$ as cut-off. The data were analysed using a commercially available statistical software package (SPSS, Chicago, IL, USA).

\section{Results}

Evaluation of the health hazards of DM consumption and nutritional and nutraceutical analyses

In raw and pasteurised milk samples, the TVC was on average $74,333.33 \mathrm{CFU} / \mathrm{mL}( \pm 34,416.57)$ and $4332.22 \mathrm{CFU} / \mathrm{mL} \quad( \pm$ 3046.78) respectively. In raw milk samples, the bacteria responsible of food-borne outbreaks (Salmonella spp., Listeria monocytogenes, Campylobacter spp.) were never detected. Moreover, coagulase-positive Staphylococci were found in the raw milk with a count ranging from $<1 \mathrm{CFU} / \mathrm{mL}$ to 190 $\mathrm{CFU} / \mathrm{mL}$, and an average value of $133.83 \mathrm{CFU} / \mathrm{mL}$. The Enterobacteria count was always lower than $1 \mathrm{CFU} / \mathrm{mL}$ in the pasteurised milk samples in compliance with Regulation (EC) No 1441/2007 and L. monocytogenes was never isolated.

DM showed a dry matter percentage of 9.32, of which the major component was lactose with a percentage of 7.05 , whereas 0.81 was the percentage of casein; fat and ash percentages were 0.31 and 0.37 respectively (Table 2). Among the minerals, calcium and potassium were present in higher quantities $(633.31$ and $653.32 \mathrm{mg} / \mathrm{L}$ respectively) while zinc was $3.16 \mathrm{mg} / \mathrm{L}$. 
As regards the milk fatty acid profile, the most frequently represented fatty acids were palmitic acid $(22.10 \mathrm{~g} / 100 \mathrm{~g}$ of fat), oleic ( $21.58 \mathrm{~g} / 100 \mathrm{~g}$ of fat), and linoleic (11.18 g/100 g of fat) (Table 3). Saturated and unsaturated fatty acids were 52 and $48 \mathrm{~g} / 100 \mathrm{~g}$ of fat respectively. Among the unsaturated, n3 fatty acids were about $8 \mathrm{~g} / 100 \mathrm{~g}$ of fat and the major $\mathrm{n}-3$ component present in milk was linolenic acid $(7.52 \mathrm{~g} / 100 \mathrm{~g}$ of fat), whereas linoleic was the main $n-6$ fatty acid; $n-3 / n-6$ ratio was 0.72 . DM showed a mean lysozyme activity of $1402+286.658 \mathrm{U} / \mathrm{ml}$ and total content of vitamin D1.97 $\mu \mathrm{g} /$ $100 \mathrm{ml}$ principally due at vitamin D2 (Table 2).

\section{Allergological work-up and palatability assessment}

The DM was well tolerated and showed good palatability both in patients with IgE-CMPA and CM-FPIES. In particular, 67 out of 70 patients with IgE-CMPA underwent the OFC, the parents of the others 3 patients refused to give their consent because of positivity to the SPT and/or s-IgE to DM. Only one out of 67 (1.5\%) patients with IgE-CMPA reacted to the DM. Of the patients with CM-FPIES, 11 out of $11(100 \%)$ underwent the OFC and all patients tolerated the DM. In general, 77 out of 78 patients (98.7\%) that underwent OFC with DM tolerated it.

\section{Nutritional plans, monitoring growth and quality of life}

Sixteen out of 66 patients with IgE-CMPA and six out of 11 patients with CM-FPIES took and tolerated the DM for the prescribed length of time. All 22 patients also followed the nutritional plans formulated for each one, without significant variations in the quantity of DM consumed.

The mean age $( \pm \mathrm{SD})$ of the patients with IgE-CMPA at T0 was 20 ( \pm 18.4 ) months (range 9-79 months). The mean

Table 2 Chemical composition of pasteurized donkey's milk

\begin{tabular}{llll}
\hline Item & Units & Mean & Standard Deviation \\
\hline Fat & $\%$ & 0.31 & 0.053 \\
Protein & $\%$ & 1.59 & 0.137 \\
Casein & $\%$ & 0.81 & 0.134 \\
Dry Matter & $\%$ & 9.32 & 0.285 \\
Ash & $\%$ & 0.37 & 0.022 \\
Lactose & $\%$ & 7.05 & 0.150 \\
Ca & $\mathrm{mg} / \mathrm{L}$ & 633.31 & 137.440 \\
P & $\mathrm{mg} / \mathrm{L}$ & 386.31 & 69.21 \\
K & $\mathrm{mg} / \mathrm{L}$ & 652.32 & 73.329 \\
Mg & $\mathrm{mg} / \mathrm{L}$ & 92.59 & 27.737 \\
Na & $\mathrm{mg} / \mathrm{L}$ & 168.20 & 72.420 \\
Zn & $\mathrm{mg} / \mathrm{L}$ & 3.16 & 1.500 \\
Total Vit. D & $\mathrm{ug} / 100 \mathrm{ml}$ & 1.97 & 0.454 \\
Vit. D2 & $\mathrm{ug} / 100 \mathrm{ml}$ & 1.72 & 0.833 \\
Vit. D3 & $\mathrm{ug} / 100 \mathrm{ml}$ & 0.25 & 0.184 \\
Lysozyme activity & $\mathrm{U} / \mathrm{ml}$ & 1402 & 286.658 \\
\hline
\end{tabular}

weight $( \pm \mathrm{SD})$ was $9.993( \pm 4.660) \mathrm{kg}$ and the mean length/ stature $( \pm \mathrm{SD})$ was $77.41( \pm 17.59) \mathrm{cm}$ at T0. The mean weight $( \pm \mathrm{SD})$ was $12.160( \pm 3.087) \mathrm{kg}$ and the mean length/ stature $( \pm \mathrm{SD})$ was $87.91( \pm 25.77) \mathrm{cm}$ at $\mathrm{T} 1$. As regards the six patients with CM-FPIES, the mean age $( \pm$ SD) at T0 was 5.33 ( \pm 1.75 ) months (range $3-8$ months), the mean weight $( \pm \mathrm{SD})$ was $7.566( \pm 3.130) \mathrm{kg}$ and the mean length/stature $( \pm$ SD) was $66( \pm 3.93) \mathrm{cm}$. The mean values $( \pm \mathrm{SD})$ for weight and length/stature at T1 were $9.470( \pm 5.194) \mathrm{kg}$ and $74.4( \pm$ $38.5) \mathrm{cm}$ respectively.

Tables 4 and 5 report the variations in the auxological values (expressed with $\Delta \mathrm{z}$-score) in the 22 patients enrolled at T0 and T1 grouped for pathology (Table 4) and in the children younger than 1 year (Table 5 ).

At T0, patients with IgE-CMPA had negative weight and length/stature Z-scores and showed an improvement at T1, statistically significant for length/stature Z-score $(p<0.05)$. Similarly, we found a statistically significant improvement for length/stature Z-score in patients younger than 1 year (Table 5). The growth in weight was similar to that of the reference population both in IgE-CMPA and in infant younger than 1 year. The infants with CM-FPIES showed a normal nutritional status from the beginning of enrolment and maintained it during the 6 months of being fed DM, with a good increase in weight and length/stature similar to the reference population.

The blood biochemical parameters with nutritional interest were evaluated in 19 patients (16 with IgECMPA and 3 with FPIES) out of 22 (86.4\%), the other 3 patients with CM-FPIES did not perform the blood tests due to refusal by their parents. No relevant variations were observed; in fact, all the blood values were always in the normal range (data not shown).

\section{Discussion}

The TVC of the raw milk was on average lower than the limit required by the Regulation (EC) 853/2004 ( $\leq 1.500 \times$ $103 \mathrm{CFU} / \mathrm{mL}$ ). In addition, TVC was lower than that described in other studies on pasteurised donkey's milk [52]. Coagulase-positive Staphylococci showed low average values below the limit of $105 \mathrm{CFU} / \mathrm{mL}$ which is considered a risk for food safety.

Although L. monocytogenes is killed by pasteurisation, it may represent a high food safety hazard in milk not properly pasteurised or contaminated after thermal treatment, especially in vulnerable subjects such as infants and pregnant women. Therefore, a careful risk assessment of L. monocytogenes can help ensure the food safety of pasteurised DM. The Enterobacteria count in the pasteurised milk samples was in compliance with Regulation (EC) No 1441/2007.

Compared to milk from other dairy species, DM is the most similar to HM [23]. In particular, the nutritional similarities concern the low content of caseins and ashes, thus limiting allergy and favouring a lower contribution of renal solutes and a high content of lactose that 
Table 3 Fatty acid composition of pasteurized donkey's milk (g/100 g of fat)

\begin{tabular}{|c|c|c|c|c|c|}
\hline Item & Mean & Standard deviation & Item & Mean & Standard deviation \\
\hline$C 4: 0$ & 0.08 & 0.021 & C18:2 t-9.12 & 0.08 & 0.066 \\
\hline C6:0 & 0.23 & 0.104 & C18:2 c-9.12 & 11.18 & 1.904 \\
\hline C $8: 0$ & 3.56 & 0.762 & C18:3 n6 & 0.13 & 0.078 \\
\hline C10:0 & 8.11 & 1.403 & C20:0 & 0.17 & 0.098 \\
\hline C11:0 & 1.31 & 0.316 & CLA c9. t11 & 0.07 & 0.045 \\
\hline $\mathrm{C} 12: 0$ & 7.66 & 1.145 & C20:1 & 0.13 & 0.090 \\
\hline C13:0 & 0.05 & 0.031 & C21:0 & 0.08 & 0.096 \\
\hline C14:0 & 6.33 & 1.061 & C20:2 & 0.13 & 0.066 \\
\hline C14:1 & 0.40 & 0.114 & $C 20: 3 n 3$ & 0.21 & 0.060 \\
\hline C15:0 & 0.39 & 0.075 & C20:3 n6 & 0.07 & 0.061 \\
\hline C15:1 & 0.17 & 0.098 & $\mathrm{C} 22: 0$ & 0.06 & 0.042 \\
\hline C16:0 & 22.10 & 2.924 & C22:1 & 0.25 & 0.052 \\
\hline C16:1 & 3.86 & 0.840 & C20:4n6 & 0.07 & 0.035 \\
\hline $\mathrm{C} 17: 0$ & 0.26 & 0.100 & $C 23: 0$ & 0.04 & 0.038 \\
\hline C17:1 & 0.40 & 0.098 & $C 22: 2$ & 0.10 & 0.087 \\
\hline C18:0 & 1.66 & 0.357 & C20:5 & 0.07 & 0.060 \\
\hline C18:1 t-9 & 0.04 & 0.004 & $\mathrm{C} 24: 0$ & 0.09 & 0.067 \\
\hline C18:1 t-11 & 0.05 & 0.035 & $C 24: 1$ & 0.06 & 0.070 \\
\hline C18:1 c-9 & 21.58 & 2.904 & C22:5 & 0.10 & 0.084 \\
\hline C18:1 c-11 & 1.08 & 0.273 & $C 22: 6$ & 0.05 & 0.041 \\
\hline C18:3n3 & 7.52 & 2.494 & & & \\
\hline SCFA $(\leq C 10)$ & 11.97 & 2.131 & SFA & 52.17 & 3.987 \\
\hline MCFA $(\geq C 11 \leq C 17)$ & 42.93 & 4.155 & MUFA & 28.05 & 3.487 \\
\hline $\operatorname{LCFA}(\geq \mathrm{C} 18)$ & 45.10 & 3.731 & PUFA & 19.79 & 2.433 \\
\hline n3/n6 ratio & 0.72 & 0.274 & UFA/SFA & 0.93 & 0.141 \\
\hline
\end{tabular}

SCFA short-chain fatty acids, MCFA medium-chain fatty acids, LCFA long-chain fatty acids, SFA saturated fatty acids, MUFA monounsaturated fatty acids, PUFA polyunsaturated fatty acids, UFA unsaturated fatty acids

Table 4 Variation of z score for weight and length/stature during DM assumption

\begin{tabular}{|c|c|c|}
\hline IgE- CMPA & T0 & $\mathrm{T} 1$ \\
\hline Number of patients & 16 & 16 \\
\hline$\Delta z$-score for the weight & -0.64 & $-0.03(+0.61)$ \\
\hline$\Delta z$-score for the length/stature & -0.80 & $0.12(+0.92)^{*}$ \\
\hline CM-FPIES & T0 & $\mathrm{T} 1$ \\
\hline Number of patients & 6 & 6 \\
\hline$\Delta z$-score for the weight & 0.16 & $0.25(+0.09)$ \\
\hline$\Delta z$-score for the length/stature & 0.11 & $0.12(+0.01)$ \\
\hline
\end{tabular}

promotes good palatability. Donkey and human milk share a similar unsaturated:saturated ratio [56]. Furthermore, the fat content in donkey's milk is lower compared other milks, and this implies a low energetic value of the milk [25]. A multidisciplinary group approach, including a dietician, is fundamental in the planning of a "personalized nutritional plan", to fully satisfy the nutritional needs of patients based on age, symptoms but also food preferences and nutritional behavior of the patient

Table 5 Variation of z score for weight and length/stature in the patient younger than one year

\begin{tabular}{lll}
\hline $0-12$ months & T0 & T1 \\
\hline Number of patients & 17 & 17 \\
$\Delta z$-score for the weight & -0.31 & $+0.25(+0.56)$ \\
$\Delta z$-score for the length/stature & -0.62 & $+0.25(+0.87) *$ \\
\hline${ }^{*} P<0.05$ & \\
T0: mean values of $z$-score at the beginning of the donkey milk assumption; \\
T1: mean values of $z$-score after 6 months of the the donkey milk assumption; \\
$\Delta z$-score: variation of the mean values of $z$ score
\end{tabular}


[57] However, our study shows that this limit can easily be overcome with appropriate supplementations.

As already described in two of our previous papers, DM is well tolerated and appreciated by children with CMPA and CM-FPIES [29, 53]. It has long been known that despite similar energy intakes, children with $\mathrm{CM}$ allergy have a shorter stature than controls without $\mathrm{CM}$ allergy, [58, 59]. Our results are in line with previous studies that show a check-up growth after the introduction of DM in children with CM allergy [25-27]. No relevant variations in terms of blood and metabolic parameters were detected.

In particular, despite major concerns regarding the use of un-modified DM as sole nutritional source (if not adequately supplemented), our results indicate that it could be considered a valid alternative in weaned infants (older than 5-6 months), and also in infants aged between 0 and 6 months with appropriate nutritional supplements. In fact, our study found that DM allowed a regular increase in weight in children aged $0-12$ months and an improvement in their length/stature growth.

A very positive aspect deriving from our study was the improvement in the quality of life of the patients and their families. The parents of the children referred to the dietitian that their children/infants were less restless and more relaxed; they ate with more pleasure and showed greater curiosity towards the various foods that were offered. Probably this improvement is mainly due to the exclusion of CM from the diet, but also to the good taste and nutritional characteristics of DM, as well as the dietetic follow-up that we offered to patients and their families. As a result, there was more serenity in the family, less anxiety, and in general, a better quality of life.

A limit in the consumption of DM as a substitute for CM remains its high cost, however, the eHFs and FAAFs are also expensive and, unlike DM, they have low palatability. Our encouraging results should potentiate the production of DM, which could lead to a reduction in its cost.

Moreover despite the encouraging results, limitations of our study were the small number of the enrolled patients and the lack of a control group. More extensive studies are needed regarding the use of DM as a substitute of CM in patients with IgE-CMPA and CM-FPIES and it would be interesting a head-to-head comparison between DM and other nutritional sources in terms of nutritional and allergenic aspects.

\section{Conclusions}

In conclusion DM resulted safe in term of health and hygiene risk and nutritionally adequate: no negative impact on the growth rate of infants and children was assessed. Therefore, it may be a suitable alternative for the management of IgE- CMPA and CMFPIES, also in the first 6 months of life, if adequately supplemented.

\section{Abbreviations}

CDC: Central Disease Control; CM: Cow's milk; CM-FPIES: Food Protein Induced Enterocolitis Syndrome; CMP: cow's milk protein; DM: donkey milk; eHFs: extensively hydrolyzed formulas; FAAFs: free amino acid formulas; HM: Human milk; IgE- CMPA: IgE-mediate cow's milk protein allergy; OFC: oral food challenge; s-lgE: specific serum IgE; SPT: skin prick test; WHO: World Health Organisation

\section{Acknowledgments \\ The authors wish to thank the Regional Government of Tuscany (Bando pubblico per progetti di ricerca nel settore Nutraceutica 2014-2015) for supporting the project "Amiata milk in the management of babies with allergies to cow's milk proteins: innovative, clinical, allergic, and nutritional aspects" and the Complesso Agricolo Forestale Regionale Bandite di Scarlino.}

\section{Authors' contributions}

All Authors have made a substantial contribution to the conception, design, analysis and interpretation of data, drafting the article and revising it critically for intellectual content; all Authors approve the final version submitted to the Italian Journal of Pediatrics.

\section{Funding}

The authors of this publication have research support from the REGIONAL GOVERNEMENT OF TUSCANY under the open call for research projects in the Nutraceuticals sector (D.D. 650/2014).

\section{Availability of data and materials}

The data that support the findings of this study are available from the authors.

Ethics approval and consent to participate

Before beginning the study informed parental consent was given.

Consent for publication

Not applicable.

\section{Competing interests}

The authors declare that they have no competing interests.

\section{Author details}

${ }^{1}$ Allergy Unit, department of Paediatrics, Anna Meyer Children's University Hospital, Florence, Italy. ${ }^{2}$ Nutrition Unit, department of Paediatrics, Anna Meyer Children's University Hospital, Florence, Italy. ${ }^{3}$ Department of Veterinary Science, University of Pisa, Pisa, Italy. ${ }^{4}$ Interdepartmental Research Center Nutraceuticals and Food for Health, University of Pisa, Pisa, Italy. ${ }^{5}$ Istituto Zooprofilattico Sperimentale del Lazio e della Toscana M. Aleandri, Florence, Italy.

Received: 30 March 2019 Accepted: 6 August 2019

Published online: 17 August 2019

\section{References}

1. World Health Organization. Protecting, promoting and supporting breastfeeding in facilities providing maternity and newborn services - Guideline; 2017.

2. Boyce JA, Assa'ad A, Burks AW, Jones SM, Sampson HA, Wood RA, Plaut M, Cooper SF, Fenton MJ, Arshad SH, Bahna SL, Beck LA, Byrd-Bredbenner C, Camargo CA Jr, Eichenfield L, Furuta GT, Hanifin JM, Jones C, Kraft M, Levy BD, Lieberman P, Luccioli S, KM MC, Schneider LC, Simon RA, Simons FE, Teach SJ, Yawn BP, Schwaninger JM. Guidelines for the diagnosis and management of food allergy in the United States: report of the NIAIDsponsored expert panel. J Allergy Clin Immunol. 2010;126:S1-58.

3. Sicherer SH. Epidemiology of food allergy. J Allergy Clin Immunol. 2011;127:594-602.

4. Katz Y, Goldberg MR, Rajuan N, Cohen A, Leshno M. The prevalence and natural course of food protein-induced enterocolitis syndrome to cow's milk: a large-scale, prospective population-based study. J Allergy Clin Immunol. 2011;127:647-53.

5. Sampson HA, Aceves S, Bock SA, James J, Jones S, Lang D. Food allergy: a practice parameter update-2014. J Allergy Clin Immunol. 2014;134:1016-25.

6. Giovannini M, D'Auria E, Caffarelli C, Verduci E, Barberi S, Indinnimeo L, lacono ID, Martelli A, Riva E, Bernardini R. Nutritional management and follow up of infants and children with food allergy: Italian Society of 
Pediatric Nutrition/Italian Society of Pediatric Allergy and Immunology Task Force Position Statement. Ital J Pediatr. 2014;40:1.

7. Nowak-Węgrzyn A, Jarocka-Cyrta E, Moschione CA. Food protein-induced enterocolitis syndrome. J Investig Allergol Clin Immunol. 2017;27:1-18.

8. Allen KJ, Davidson GP, Day AS, Hill DJ, Kemp AS, Peake JE, et al. Management of cow's milk protein allergy in infants and young children: an expert panel perspective. J Paediatr Child Health. 2009;45:481-6.

9. Walsh J, O'Flynn N. Diagnosis and assessment of food allergy in children and young people in primary care and community settings: NICE clinical guideline. Br J Gen Pract. 2011;61:473-5.

10. Fiocchi A, Brozek J, Schünemann H, Bahna SL, von Berg A, Beyer K, et al. World allergy organization (WAO) diagnosis and rationale for action against Cow's Milk allergy (DRACMA) guidelines. World Allergy Organ J. 2010;3:57-161.

11. Koletzko S, Niggemann B, Arato A, European Society of Pediatric Gastroenterology, hepatology, and nutrition. Diagnostic approach and management of cow's milk protein allergy in infants and children: ESPGHAN GI Committee practical guidelines. J Pediatr Gastroenterol Nutr. 2012;55:221-9.

12. Muraro A, Werfel T, Hoffmann-Sommergruber K, Roberts G, Beyer $K$, Bindslev-Jensen C. EAACl food allergy and anaphylaxis guidelines group. EAACl food allergy and anaphylaxis guidelines: diagnosis and management of food allergy. Allergy. 2014:69:1008-25.

13. Luyt D, Ball H, Makwana N, Green MR, Bravin K, Nasser SM. Standards of care committee (SOCC) of the British Society for Allergy and Clinical Immunology (BSACI). BSACl guideline for the diagnosis and management of Cow's milk allergy. Clin Exp Allergy. 2014;44:642-72.

14. Caffarelli C, Plebani A, Poiesi C, Petroccione T, Spattini A, Cavagni G. Determination of allergenicity to three cow's milk hydrolysates and an amino acid-derived formula in children with cow's milk allergy. Clin Exp Allergy. 2002;32:74-9.

15. Miraglia Del Giudice M, D'Auria E, Peroni D, Palazzo S, Radaelli G, Comberiati P, Galdo F, Maiello N, Riva E. Flavor, relative palatability and components of cow's milk hydrolysed formulas and amino acid-based formula. Ital J Pediatr. 2015;41:42.

16. de Boissieu D, Matarazzo P, Dupont C. Allergy to extensively hydrolyzed cow milk proteins in infants: identification and treatment with an amino acid-based formula. J Pediatr. 1997;131:744-7.

17. Meyer R, Groetch M, Venter C. When should infants with Cow's Milk protein allergy use an amino acid formula? A practical guide. J Allergy Clin Immunol Pract. 2018:6:383-99.

18. Muraro MA, Giampietro PG, Galli E. Soy formulas and nonbovine milk. Ann Allergy Asthma Immunol. 2002;89:97-101.

19. Candreva AM, Smaldini PL, Curciarello R, Cauerhff A, Fossati CA, Docena GH, Petruccelli S. Cross-reactivity between the soybean protein p34 and bovine caseins. Allergy, Asthma Immunol Res. 2015;7:60-8.

20. Nowak-Wegrzyn A, Sampson HA, Wood RA, Sicherer SH. Food protein-induced enterocolitis syndrome caused by solid food proteins. Pediatrics. 2003;111:829-35.

21. Ruffner MA, Ruymann K, Barni S, Cianferoni A, Brown-Whitehorn T, Spergel $J M$. Food protein-induced enterocolitis syndrome: insights from review of a large referral population. J Allergy Clin Immunol Pract. 2013;1:343-9.

22. Caubet JC, Ford LS, Sickles L, Jäninen KM, Sicherer SH, Sampson HA, NowakWęgrzyn A. Clinical features and resolution of food protein-induced enterocolitis syndrome: 10-year experience. J Allergy Clin Immunol. 2014;134:382-9.

23. Martini M, Altomonte I, Licitra R, Salari F. Nutritional and nutraceutical quality of donkey Milk. Journal of Equine Veterinary Science. 2018;65:33-7.

24. lacono G, Carroccio A, Cavataio F, Montalto G, Soresi M, Balsamo V. Use of ass' milk in multiple food allergy. J Pediatr Gastroenterol Nutr. 1992;14:177-81.

25. Monti G, Bertino E, Muratore MC, Coscia A, Cresi F, Silvestro L, Fabris C, Fortunato D, Giuffrida MG, Conti A. Efficacy of donkey's milk in treating highly problematic cow's milk allergic children: an in vivo and in vitro study. Pediatr Allergy Immunol. 2007;18:258-64.

26. Monti G, Viola S, Baro C, Cresi F, Tovo PA, Moro G, Ferrero MP, Conti A, Bertino E. Tolerability of donkey's milk in 92 highly problematic cow's milk allergic children. J Biol Regul Homeost Agents. 2012;26:75-82.

27. Tesse R, Paglialunga C, Braccio S, Armenio L. Adequacy and tolerance to ass's milk in an Italian cohort of children with cow's milk allergy. Ital J Pediatr. 2009;9:35-19.

28. Carroccio A, Cavataio F, Montalto G, D' Amico D, Alabrese L, lacono G. Intolerance to hydrolysed cow's milk proteins in infants: clinical characteristics and dietary treatment. Clin Exp Allergy. 2000;30:1597-603.

29. Mori F, Sarti L, Barni S, Pucci N, Belli F, Stagi S, Novembre E. Donkey's milk is well accepted and tolerated by infants with cow's milk food proteininduced enterocolitis syndrome: a preliminary study. J Investig Allergol Clin Immunol. 2017;27:269-71.
30. Infante PD, Tormo CR, Conde ZM. Use of goat's milk in patient with cow's milk allergy. Ann Pediatr (Barc). 2003;59:138-42.

31. Pessler F, Nejat M. Anaphylactic reaction to goat's milk in a cow's milk allergic infant. Pediatr Allergy Immunol. 2004;15:183-5.

32. D'Auria E, Agostoni C, Giovannini M. Proteomic evaluation of milk from different mammalian species as a substitute for breast milk. Acta Paediatr. 2005;94:1708-13.

33. Coppola R, Salimei E, Succi M. Behaviour of lactobacillus rhamnosus strains in ass's milk. Ann Microbiol. 2002;52:55-60.

34. Cunsolo V, Saletti R, Muccilli V, Gallina S, Di Francesco A, Foti S. Proteins and bioactive peptides from donkey milk: the molecular basis for its reduced allergenic properties. Food Res Int. 2017;99:41-57.

35. Vincenzetti S, Foghini L, Pucciarelli S, Polzonetti V, Cammertoni N, Beghelli D, Polidori P. Hypoallergenic properties of donkey's milk: a preliminary study. Vet Ital. 2014;50:99-107.

36. Areco V, Rivoira MA, Rodriguez V, Marchionatti A, Carpentieri A, Tolosa de Talamoni N. Dietary and pharmacological compounds altering intestinal calcium absorption in humans and animals. Nutr Res Rev. 2015;28:83-99.

37. Kwak HS, Lee WJ, Lee MR. Revisiting lactose as an enhancer of calcium absorption. Int Dairy J. 2012;22:147-51.

38. Vincenzetti S, Polidori P, Mariani P, Cammertoni N, Fantuz F, Vita A. Donkey's milk protein fractions characterization. Food Chem. 2008;106:640-9.

39. Ragona G, Comias F, Benedetti M, Paladini M, Salari F, Attomonte I, Martini M. Amiata donkey Milk chain: animal health evaluation and Milk quality. Ital J Food Saf. 2016;5:5951.

40. Šarić LĆ, Šarić BM, Mandić Al, Torbica AM, Tomić JM, Cvetković DD, Okanović DG. Antibacterial properties of domestic Balkan donkeys' milk. Int Dairy J. 2012;25:142-6.

41. Colavita G, Amadoro C, Rossi F, Fantuz F, Salimei E. Hygienic characteristics and microbiological hazard identification in horse and donkey raw milk. Vet Ital. 2016;52:21-9.

42. Pilla R, Daprà V, Zecconi A, Piccinini R. Hygienic and health characteristics of donkey milk during a follow-up study. J Dairy Res. 2010;77:392-7.

43. Mancianti F, Nardoni S, Papini R, Mugnaini L, Martini M, Altomonte I, Salari F, D'Ascenzi C, Dubey JP. Detection and genotyping of toxoplasma gondii DNA in the blood and milk of naturally infected donkeys (Equus asinus). Parasit Vectors. 2014:7:165.

44. AOAC (Association of Official Analytical Chemists). Official methods of analysis. Gaithersburg: AOAC International; 2004.

45. AOAC (Association of Official Analytical Chemists). Official methods of analysis, 16th edn. Vol. II. Arlington: AOAC International; 1995.

46. Horvitz W. AOAC (Association of Official Analytical Chemists). Official Method of Analysis of AOAC International. 17th edition. Gaithersburg: AOAC International; 2000.

47. Murthy GK, Rhea U. Determination of major cations in milk by atomic absorption spectrophotometry. J Dairy Sci. 1967;50:313-7.

48. Christie WW. A simple procedure of rapid transmethylation of glycerolipids and cholesteryl esters. J Lipid Res. 1982;23:1072-5.

49. Perales $S$, Alegría $A$, Barberá R, Farré R. Review: determination of vitamin $D$ in dairy products by high performance liquid chromatography. Food Sci Technol Int. 2005;11:451-62.

50. Hagar AF, Madsen L, Wales L, Bradfor HB. Reversed-phase liquid chromatographic determination of vitamin D in milk. J AOAC INTERNATIONAL. 1994;77:1047-51.

51. Fiocchi A, Brozek J, Schünemann H, Bahna SL, von Berg A, Beyer K, Bozzola M, Bradsher J, Compalati E, Ebisawa M, Guzmán MA, Li H, Heine RG, Keith P, Lack G, Landi M, Martelli A, Rancé F, Sampson H, Stein A, Terracciano L, Vieths S. World allergy organization (WAO) special committee on food allergy. World allergy organization (WAO) diagnosis and rationale for action against Cow's Milk allergy (DRACMA) guidelines. Pediatr Allergy Immunol. 2010;21:1-125.

52. Leonard SA, Nowak-Wegrzyn A. Food protein-induced enterocolitis syndrome: an updateon natural history and review of management. Ann Allergy Asthma Immunol. 2011;107:95-101.

53. Barni S, Sarti L, Mori F, Muscas G, Belli F, Pucci N, Novembre E. Tolerability and palatability of donkey's milk in children with cow's milk allergy. Pediatr Allergy Immunol. 2018;29:329-31.

54. WHO Multicentre Growth Reference Study Group. WHO child growth standards: length/height-for-age, weight-for-age, weight-for-length, weightfor-height and body mass index-for-age: methods and development. Geneva: World Health Organization; 2006.

55. The National Center for Health Statistics in collaboration with the National Center for Chronic Disease Prevention and Health Promotion; Growth Charts; May 30, 2000 (modified 10/16/00). 
56. Martini M, Altomonte I, Salari F. Amiata donkeys: fat globule characteristics, milk gross composition and fatty acids. Ital J Anim Sci. 2014;13:123-6.

57. D'Auria E, Abrahams M, Zuccotti GV, Venter C. Personalized nutrition approach in food allergy: is it prime time yet? Nutrients. 2019;11:359.

58. Tiainen JM, Nuutinen OM, Kalavainen MP. Diet and nutritional status in children with cow's milk allergy. Eur J Clin Nutr. 1995;49:605-12.

59. Isolauri E, Sutas Y, Salo MK, Isosomppi R, Kaila M. Elimination diet in cow's milk allergy: risk for impaired growth in young children. J Pediatr. 1998;132:1004-9.

\section{Publisher's Note}

Springer Nature remains neutral with regard to jurisdictional claims in published maps and institutional affiliations.

Ready to submit your research? Choose BMC and benefit from:

- fast, convenient online submission

- thorough peer review by experienced researchers in your field

- rapid publication on acceptance

- support for research data, including large and complex data types

- gold Open Access which fosters wider collaboration and increased citations

- maximum visibility for your research: over $100 \mathrm{M}$ website views per year

At $\mathrm{BMC}$, research is always in progress.

Learn more biomedcentral.com/submissions 